\title{
INSECTS
}

\section{FLEAS GATHERED FROM MAMMALS COLLECTED ON THE MCINTYRE RANCH OF SOUTHERN ALBERTA}

HUGH C. SMITH, 506 - 75 Gervais Road, St. Albert, AB. T8N 6N2.

\section{Introduction}

The flea fauna of Alberta is well known with respect to the species that occur, and their distribution. This is due to the work of a number of people especially G. P. Holland. His published work, The Fleas of Canada, Alaska and Greenland (Siphonaptera), is the basis for most of our knowledge of fleas of this area. ${ }^{2}$ There are However, areas of the province that have not been surveyed. Small regional studies provide information that will allow for a better understanding of the distribution of this group of animals. Biodiversity is the current catch-phrase for many ecological studies today. However, such studies typically concentrate on only a selected segment of the flora or fauna of an area, such as the birds or mammals or flowering plants or trees. An examination of the ectoparasites of these life-forms is seldom undertaken even though the effects of parasites on their hosts may be substantial. With this in mind, I examined specimens of mammals for ectoparasites, Specifically fleas that were collected as a part of a biological survey of the Mclntyre Ranch by the Provincial Museum of Alberta. Unfortunately, I was not able to examine all the specimens. In total, 212 mammals representing 20 species were collected in three years. ${ }^{1}$ For a complete description of the McIntyre Ranch see the report "A Bioinventory of Mclntyre Ranch: An Extensive Fescue-Dominated
Grassland in Southern Alberta", edited by W. B. McGillvray and M. Steinhilber, prepared by the Provincial Museum of Alberta, Edmonton. ${ }^{3}$

Briefly, the Mclntyre Ranch is located in southern Alberta, $16 \mathrm{~km}$ south of Magrath and occupies 87 sections of land on the Milk River Ridge. The mammalian fauna was surveyed in 1990, 1991, and 19931. The fleas discussed in this note were obtained from mammals collected in 1990. Prior to being prepared in the Museum, the hair of a specimen was examined for fleas. All fleas collected were preserved in alcohol for later preparation and identification. The fleas were cleared and mounted on microscope slides and are stored in the entomological collection of the Provincial Museum of Alberta. Identifications were made using the keys in Holland. ${ }^{2}$ The names used are also from that publication.

\section{Species List}

Cediopsylla inaequalis inaequalis (Baker)

Specimens collected: 21 females 15 males

This is a western North American flea that is associated with cottontails and hares. Two Nuttall's Cottontails (Sylvilagus nuttallii) were collected on the Mclntyre Ranch. All the fleas 
collected were obtained from one cottontail. Holland ${ }^{2}$ indicated that the range of this flea in Alberta extends west to Waterton Lakes National Park. The location of the Mclntyre Ranch is within this range.

\section{Catallagia decipiens Rothschild}

Specimens Collected: 1 female 1 male

This is a common and widely distributed flea in Alberta $^{2}$. It has also been found on a variety of hosts. On the McIntyre Ranch, only two specimens were collected, one from a Deer Mouse (Peromyscus maniculatus) and one from a Meadow Vole (Microtus pennsylvanicus). The locality records, Anderson Lake and Pothole Creek, are within the range of this species as outlined by Holland ${ }^{2}$.

\section{Epitedia wenmanni wenmanni (Rothschild)}

Specimens Collected: 1 female 1 male

This is another common and widely distributed flea in Alberta $^{2}$. It is also found on a number of hosts. In this study, the specimens were collected at Anderson Lake and Pothole Creek from a Deer Mouse and a Meadow Vole. Anderson Lake and Pothole Creek are localities not reported by Holland ${ }^{2}$.

\section{Rhadinopsylla fraterna (Baker)}

\section{Specimens Collected: 1 male}

This flea is found on a number of hosts but is essentially closely associated with Richardson's Ground Squirrel (Spermophilus richardsonii). Bryant ${ }^{1}$ listed the Richardson's Ground Squirrel as abundant at McIntyre Ranch but only three specimens were collected and none provided any fleas. The flea specimen referred to here was obtained from one of two Sagebrush Voles (Lagurus curtatus) that were collected on the Ranch.

Myodopsylla insignis (Rothschild)

Specimens Collected: 14 females

This is a common flea of bats ${ }^{2}$. At Mclntyre Ranch, 12 Little Brown Bats (Myotis lucifugus) were collected, five were found to harbour this flea. The number of fleas per bat ranged from 1 to 5 . The bats roosted in a bunkhouse on the Ranch property ${ }^{1}$.

Myodopsylla gentilis (Jordan and Rothschild)

Specimens Collected: 2 females and 3 males

In Alberta, this flea is considerably less common than the previous species ${ }^{2}$. Like that species, it is closely associated with the Little Brown Bat. Holland ${ }^{2}$ expressed a caution about distinguishing this species from Myodopsylla insignis on the basis of females. He did, however, indicate that the males of each species were readily separable.

\section{Ondontopsylla dentatus (Baker)}

Specimens Collected: 1 male

Nuttall's Cottontail is the exclusive host for this $\mathrm{flea}^{2}$. Besides the record listed here, there are only two other reports for this flea from Alberta ${ }^{2}$. It is considered rare in Alberta. The locality record is Pothole Creek, a locality not recorded by Holland ${ }^{2}$.

Monopsylla wagneri systaltus (Jordan)

Specimens Collected: 2 females 9 males 
A variety of rodents host this common flea $^{2}$ but the Deer Mouse is a favoured host in Alberta. On the McIntyre Ranch, si Deer Mice were found to harbour this flea. The number of individual fleas per mouse ranged from 1 to 3 . Specimens were collected from Anderson Lake and Pothole Creek, neither locality was reported by Holland ${ }^{2}$.

Megabothris asio megacolpus (Jordan)

Specimens Collected: 1 male

Holland ${ }^{2}$ shows this species to be widely distributed in Alberta. Although closely associated with the Meadow Vole, large numbers have not been collected. On the Mclntyre Ranch, the specimen referred to here was collected from near Pothole Creek from a Meadow Vole.

\section{Malaraeus telchinus (Rothschild)}

Specimens Collected: 4 females 2 males

This is an uncommon or rare flea in Alberta $^{2}$. Prior to this collection, it had been reported from only one other location in Alberta. On the Mclntyre Ranch, this species was collected at two sites: from a Deer Mouse at Pothole Creek and from a Sagebrush Vole from East Pothole Creek. Holland ${ }^{2}$ does not include this area is his list of locales nor does he include either the Deer Mouse or the Sagebrush Vole as hosts in Alberta.

\section{Oropsylla rupestris (Jordan)}

Specimens Collected: 1 female 1 male

Holland ${ }^{2}$ indicates that the Richardson's Ground Squirrel is the principal host for this common flea. During the current study only three Richardson's Ground Squirrels were collected and none was examined for ectoparasites. The specimens reported here were both from one Deer Mouse that was collected along Pothole Creek.

\section{Discussion}

Although this is an extremely small survey of fleas from a very small area in Alberta, some interesting observations were made. A total of 81 flea specimens representing 11 species was collected. Holland is, at present, the definitive text for the distribution of fleas in Canada. ${ }^{2}$ All locality records for the McIntyre Ranch are new records not reported in Holland. ${ }^{2}$ Of the 11 species of fleas discussed above, two species (Ondontopsylla dentatus and Malaraeus telchinus) are considered rare or uncommon by Holland. ${ }^{2}$ Two species (Myodopsylla insignis and Myodopsylla gentilis) are restricted to bats. The two most commonly collected mammals on the McIntyre Ranch (Deer Mouse and Meadow Vole) were also found to be host to the most flea species. Five flea species were found on Deer Mice and three species of fleas were found on Meadow Voles. It is unfortunate that many mammal collectors do not take the opportunity to examine their specimens for ectoparasites. I know from personal experience that this is one aspect of biological surveys of mammals that is sorely lacking. If a more concerted effort was made to collect ectoparasites when the opportunity presents itself our knowledge of these interesting and important animals would be greatly increased.

\section{Literature Cited}

1. Bryant, H. N. 1996. The mammals of Mclntyre Ranch. Pp. 107-116 in A Bioinventory of Mclntyre Ranch: An Extensive Fescue-Dominated Grassland in Southern Alberta (McGillvray, W. B. and M. Steinhilber, eds.) Natural History Occasional Paper 
No. 22. Provincial Museum of Alberta, Edmonton, Alberta.

2. Holland, G. P. 1985. The Fleas of Canada, Alaska and Greenland (Siphonaptera). Memoirs of the Entomological Society of Canada, No. 130. Ottawa, Ontario.
3. McGillvray, W. B. and M. Steinhilber. 1996. A Bioinventory of McIntyre Ranch: An Extensive Fescue-Dominated Grassland in Southern Alberta. Natural History Occasional Paper No. 22. Provincial Museum of Alberta, Edmonton, Alberta. 116 pp.

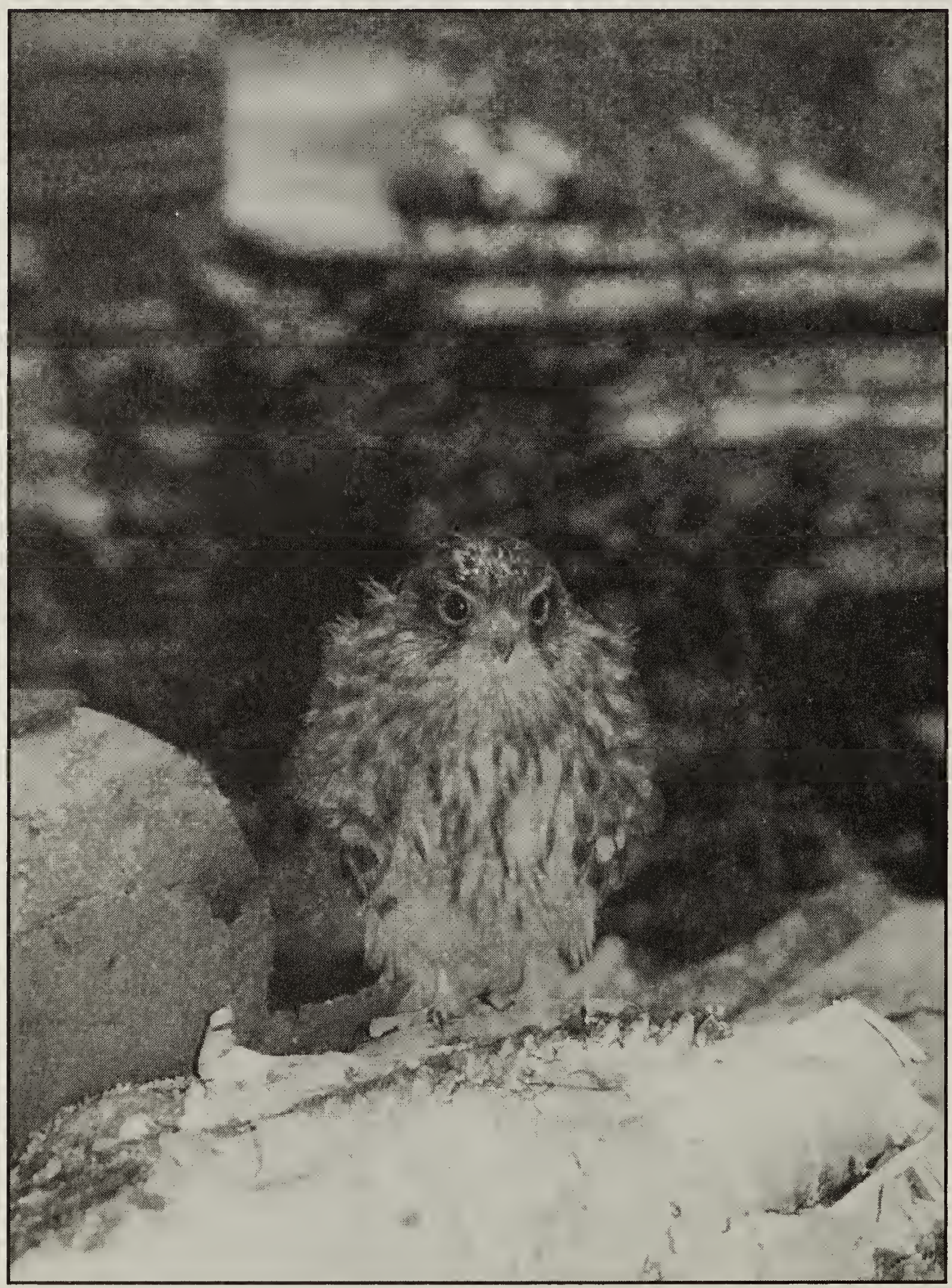

